\title{
Daily global solar radiation estimation based on air temperature: case of study south of Algeria
}

\author{
Razika Ihaddadene ${ }^{1}$, Nabila Ihaddadene $^{1}$, Mohamed El Hacen Ould Ahmedou Bemba $\mathrm{Jed}^{1}$ and Amaury De Souza ${ }^{2}$ \\ ${ }^{1}$ Departement of Mechanics, $\mathrm{M}^{\text {ed }}$ Boudiaf University M'sila, Algeria \\ ${ }^{2}$ Federal University of Mato-Grosso do Sul, C. P. 549, 79070-900 Campo Grande, MS, Brazil
}

\begin{abstract}
Global solar radiation is needed for the analysis and scaling of solar conversion systems; however, global measurements of solar radiation are not available in all Algerian cities. The use of empirical models using an accessible parameter is a solution to this problem. In this study, seven empirical Models namely Hargreaves and Samani, Chen, M.F. Li, H.Li, Bristow and Campbell, Okonkwo and Abraha Savage have been employed to estimate daily average global solar radiation on the horizontal surface. These models use extreme temperatures (minimum and maximum). They were applied to three south Algerian sites (Biskra, Ghardaia, and Tamanrasset). The analyzed data were provided by the NASA site and cover four years (2001-2004). The validation of the models for predicting daily global solar radiation was done using four statistical parameters ( $\mathrm{R}^{2}, \mathrm{MBE}, \mathrm{RMSE}$, and RPE). The results show that Bristow and Compbell Model shows better performance than the other models in all sites. A new model is proposed for each site. The results show that this later is the best one compared with the seven models analyzed. Therefore, the developed model can be suggested to estimate daily global solar radiation using only extreme air temperatures in south Algeria.
\end{abstract}

\section{Introduction}

Due to its geographic location, Algeria has the largest solar field in the world. The sunshine duration of virtually all the national territory exceeds 2000 hours annually and can reach 3900 hours in High lands and in Sahara. The daily-obtained energy on a horizontal surface of $1 \mathrm{~m}^{2}$ is about $5 \mathrm{kWh}$ over the major part of the national territory, or about $1700 \mathrm{kWh} / \mathrm{m}^{2} /$ year in the north and 2263 $\mathrm{kWh} / \mathrm{m}^{2} /$ year in the south of the country [1]. The measurement stations of various components of solar radiation are scarce or almost non-existent on all the national territory. While general meteorological parameters (pressure, temperature ( $\max$ and $\min$ ), sunshine duration, humidity, wind speed ..., etc.) are available at Meteorology National Office stations. Therefore, it is interesting to develop mathematical models to describe the various components of solar radiation as a function of these parameters.

Numerous models have been established to estimate the amount of global solar radiation on a horizontal surface using various climatic parameters, such as sunshine duration[2,3,4], cloud cover[2,5,6], humidity[7], maximum and minimum ambient temperatures $[8,9,10,11,12,13]$, wind speed...etc.

Several studies have shown that performing models use sunshine duration data followed by those using cloudiness and temperature data [14-15] respectively. However, sunshine duration data are not as readily available as air temperature data at standard meteorological stations, while, the temperature is an interesting and easily accessible meteorological parameter. Therefore, it is important to elaborate models that estimate solar radiation based on air temperature only. Due to the availability of daily maximum and minimum air temperature, several empirical models have been proposed to estimate solar radiation from these variables. Hargreaves and Samani[8] proposed the first empirical model to estimate solar radiation using only maximum and minimum air temperatures. Another model was proposed by Bristow and Campbell[11]. This later is a simple model with different configurations, in which; global solar radiation $G$ is an exponential function of temperature difference. These two models have been a subject of several modifications, which comprise adding further parameters or introducing other meteorological variables.

Based on the work of Hargreaves and Samani, Allen suggested employing a self-calibrating model to estimate mean monthly global solar radiation [10]. Chen et al. [11] have refined the Hargreaves and Samani model by adding another coefficient. Samani et al. [14] have replaced the constant of Hargreaves and Samani model by a polynomial function of second order of temperature difference.

In addition, $\mathrm{H} \mathrm{Li}$ et al. [15] proposed a modification of the Chen model by assuming that the coefficient of Hargreaves and Samani model is a linear function of the average temperature. Danatelli and Campbell [16] have modified the Bristow and Campbell model by taking into 
account two corrective functions of the mean and minimum air temperatures. Goodin et al. [17] have refined the Bristow and Campbell model by adding a $\mathrm{G}_{0^{-}}$ term meant to act as a scaling factor allowing temperature difference $\left(\mathrm{T}_{\max }-\mathrm{T}_{\min }\right)$ to accommodate a greater range of $\mathrm{G}$ values.

Similarly, other modifications were made to Hargreaves and Samani model by Weiss et al. [18] Abraha et al. [19], and Almorox et al. [1]. Li et al. [20] proposed another form of the evolution of global solar radiation as a function of the minimum and maximum temperatures. Okonkwo et al [21] have proposed a model for estimating global solar radiation received on a horizontal surface in Minna using a polynomial function of the third order of temperature ratio $\mathrm{T}_{\min } / \mathrm{T}_{\max }$.

The global solar radiation measurements are not generally operational in all cities of Algeria, due to the high cost of acquisition, maintenance, calibration and technical complexities. To overcome this problem, the use of empirical models is necessary. In this study, an analysis of the possibility of reliably estimating daily global solar radiation, from air temperature data in three cities of south Algeria; Biskra, Ghardaia, and Tamanrasset is proposed. The objectives of this study are, firstly to evaluate the accuracy and applicability of seven models that use the extraterrestrial radiation and air temperatures (maximum and minimum) to the three cities, and then select the most accurate model which estimates the daily global solar radiation for each city. Secondarily, to develop a simple new model that gives a good estimation of daily global solar radiation from the maximum and minimum daily temperatures of the same regions cited above. Then the performance of the developed model is validated for each city by comparing it, with measured data using different statistical tests.

\section{Materials and methods}

\subsection{Collection data}

In order to evaluate the applicability and accuracy of the seven models used for computing the daily global solar radiation on a horizontal surface, the geographical and meteorological data of the three south Algerian cities (Biskra, Ghardaia, and Tamanrasset) are used. The latitude, longitude and elevation for each location are presented in Table1.

Table 1. The cities terrestrial coordinates.

\begin{tabular}{|c|c|c|c|}
\hline Cities & Latitude & Longitude & Altitude(m) \\
\hline Biskra & $34^{\circ} 41^{\prime}$ & $5^{\circ} 44^{\prime}$ & 87. \\
\hline Ghardaia & $32^{\circ} 29^{\prime}$ & $3^{\circ} 41^{\prime}$ & 461 \\
\hline Tamanrasset & $22^{\circ} 47^{\prime}$ & $5^{\circ} 31$ & 1400 \\
\hline
\end{tabular}

The daily global solar radiation data and temperature data (maximum and minimum temperatures) of each city, varied from the first January until the 31 st December of the years of 2001, 2002, 2003 and 2004. These data were provided by the NASA web site.

\subsection{Models description}

Seven models are used in this study; they describe the solar radiation as a function of extraterrestrial radiation and maximum and minimum temperature. Extraterrestrial radiation is given as follows:

$G_{0}=\left(\frac{24 x 60}{\pi}\right) I_{s c} d_{r}\left[\cos (\varphi) \cos (\delta) \sin \left(\omega_{s}\right)+\omega_{s} \sin (\varphi) \sin (\delta)\right]$ (1)

where:

$I_{\mathrm{sc}}$ : the solar constant (equal to $1367 \mathrm{~W} / \mathrm{m}^{2}$ ),

$\mathrm{d}_{\mathrm{r}}$ :the relative earth-sun distance, it is given by the following formula:

$$
d_{r}=1+0.033 \cos \left(\frac{2 \pi}{365} j\right)
$$

$\mathrm{j}:$ the number of day,

$\varphi$ : the latitude of the location under consideration (in radian),

$\delta:$ the solar declination (expressed in radian), it is given as :

$$
\delta=0.4093 \sin \left(\frac{2 \pi}{365}(248+j)\right)
$$

$\omega_{\mathrm{s}}$ : the sunset hour angle, it is given by the following expression :

$$
\omega_{s}=\operatorname{arc}[-\tan (\varphi) \tan (\delta)](4)
$$

Brief descriptions of the models employed in this analysis are as follows:

\subsubsection{Hargeaves and Samani Model (Model 1)}

This model estimates the global solar radiation using only maximum and minimum temperature; Hargeaves and Samani have developed the following correlation [8]:

$$
G / G_{0}=a_{1}+\left(T_{\max }-T_{\min }\right)^{0.5}(5)
$$

where:

$\mathrm{G}$ : is the monthly average daily global solar radiation $\left[\mathrm{kWh} / \mathrm{m}^{2}\right]$,

$\mathrm{G}_{0}$ : is the monthly average daily extraterrestrial solar radiation $\left[\mathrm{kWh} / \mathrm{m}^{2}\right]$,

$\mathrm{a}_{1}:$ is an empirical coefficient.

\subsubsection{Chen Model (Model 2)}

Chen et al. [11] have modified the model of Hargreaves and Samani by introducing an empirical coefficient, $b_{2}$ as given by the following equation:

$$
G / G_{0}=a_{2}+\left(T_{\max }-T_{\min }\right)^{0.5}+b_{2}(6)
$$

\subsubsection{F. Li Model (Model 3)}

Li et al. [20] suggested the following correlation to estimate the daily global solar radiation as a function of minimum temperature $\left(\mathrm{T}_{\min }\right)$ and maximum temperature 
$\left(\mathrm{T}_{\max }\right)$ as follows:

$G / G_{0}=a_{3}+b_{3} T_{\text {max }}+c_{3} T_{\text {min }}$

Where, $\mathrm{a}_{3}, \mathrm{~b}_{3}$ and $\mathrm{c}_{3}$ are empirical coefficients.

\subsubsection{H. Li Model (Model 4)}

Li et al. [15] proposed a model to estimate monthly average global solar radiation for all climatic regions in China. This model is the result of changes made to the models of Hargeaves \& Samani and Chen. It is a function of the temperature difference $\Delta \mathrm{T}\left(\mathrm{T}_{\max }-\mathrm{T}_{\min }\right)$ and average air temperature $\mathrm{T}_{\mathrm{a}}$. Li et al. model [10] is given as follows:

$G / G_{0}=\left(a_{4}+b_{4} T_{a}\right) \Delta T^{0.5}+c_{4}(8)$

Where:

$\mathrm{T}_{\mathrm{a}}$ : is the monthly average air temperature $\left({ }^{\circ} \mathrm{C}\right)$, defined as follows:

$T_{a}=\left(T_{\max }+T_{\min }\right) / 2$

$\mathrm{a}_{4}, \mathrm{~b}_{4}$ and $\mathrm{c}_{4}$ are empirical coefficients.

\subsubsection{Bristow and Compbell Model (Model 5)}

Bristow and Compbell [9] proposed a model to estimate the daily global solar radiation as an exponential function of the air temperature difference $\left(\Delta \mathrm{T}=\mathrm{T}_{\max }-\mathrm{T}_{\min }\right)$ as noted below:

$G / G_{0}=a_{5}\left[1-\exp \left(-b_{5} \Delta T^{c_{5}}\right)\right]$

$a_{5}, b_{5}$ and $c_{5}$ are the empirical coefficients of this model.

\subsubsection{Okonkwo Model (Model 6)}

Okonkwo et al. [21] proposed a new model for estimating global solar radiation in Minna (Nigeria) by using a quadratic model based on the temperature ratio $\left(\mathrm{T}_{\min } / \mathrm{T}_{\max }\right)$. It is given by the following formula: $G / G_{0}=a_{6}+b_{6}\left(T_{\min } / T_{\max }\right)$

$+c_{6}\left(T_{\min } / T_{\max }\right)^{2}+d_{6}\left(T_{\min } / T_{\max }\right)^{3}$

$\mathrm{a}_{6}, \mathrm{~b}_{6}, \mathrm{c}_{6}$ and $\mathrm{d}_{6}$ are the empirical coefficients of this model.

\subsubsection{Abraha Savage Model (Model 7)}

Abraha Savage [22] proposed a new model for estimating global solar radiation in Cortez (Colorado, USA), Davis (California, USA), Padova (Italy), Rothamsted (UK), Wageningen (Netherlands), Pretoria (South Africa), Griffith (Australia) by using an exponential model based on the temperature difference $\left(\mathrm{T}_{\max }-\mathrm{T}_{\min }\right)$. It is given by the following formula:

$$
G / G_{0}=0.75 \times\left[1-\exp \left(-a_{7} \Delta T^{2} / \Delta T_{m}\right)\right]
$$

$\mathrm{a}_{7}$ is the empirical coefficient of this model and $\Delta \mathrm{T}_{\mathrm{m}}$ is the medium value of temperature difference.

\subsection{Models performance validation}

To illustrate the agreement between predicted and measured values of global solar radiation of the seven models, four types of judgment criterion were used; the coefficient of determination $\left(\mathrm{R}^{2}\right)$, the root mean square error (RMSE), the mean bias error (MBE), and the mean percentage error (MPE). They are frequently used to evaluate the models' performance $[23,24,25]$.

\section{Results and discussion}

In this study, seven empirical models mentioned above namely; Model 1, Model 2, Model 3, Model 4, Model 5, Model 6 and Model 7 are compared in order to determine their suitability to estimate the global solar radiation received on a horizontal surface at three south Algerian cities (Biskra, Ghardaia and Tamanrasset). The empirical coefficients of those models obtained using Matlab software from the daily global solar radiation data of the cited sites are regrouped in Table 2.

Table 2. Emperical coefficients values of the models in selected cities.

\begin{tabular}{|l|c|l|l|l|}
\hline Models & $\mathrm{a}$ & $\mathrm{b}$ & $\mathrm{c}$ & $\mathrm{d}$ \\
\hline Mod1 & & & & \\
Bis & 0,143 & & & \\
Gha & 0,146 & & & \\
Tam & 0,146 & & & \\
\hline Mod2 & & & & \\
Bis & 0,006 & 60,494 & & \\
Gha & 0,007 & 0,494 & & \\
Tam & 0,002 & 0,628 & & \\
\hline Mod3 & & & & \\
Bis & 0,374 & 0,007 & $-0,0003$ & \\
Gha & 0,401 & 0,008 & $-0,0009$ & \\
Tam & 0,601 & 0,003 & $-0,002$ & \\
\hline Mod4 & & & & \\
Bis & $-0,0006$ & 0,002 & 0,442 & \\
Gha & 0,007 & 0,002 & 0,448 & \\
Tam & 0,018 & 0,0001 & 0,570 & \\
\hline Mod5 & & & & \\
Bis & 0,606 & 0,0007 & 3,21 & \\
Gha & 0,649 & 0,006 & 2,26 & \\
Tam & 8,72 & 0,063 & 0,08 & \\
\hline Mod6 & & & & \\
Bis & 0,539 & $-0,088$ & 0,503 & $-0,067$ \\
Gha & 0,529 & 0,327 & $-0,614$ & 0,919 \\
Tam & 0,674 & 0,063 & $-0,056$ & $-0,080$ \\
\hline Mod7 & & & & \\
Bis & 0,065 & & & \\
Gha & 0,073 & & & \\
Tam & 0,102 & & & \\
\hline & & & & \\
\hline
\end{tabular}

After determining the coefficients of each model, the global solar radiation value for each day following each model is calculated. A comparison between the computed and measured values of daily global solar radiation was performed using the statistical indicators cited above $\left(\mathrm{R}^{2}\right.$, RMSE, MBE, and MPE). The values of these statistical indicators are regrouped in Table 3. As the statistical analysis shows Model 7 (Abraha Savage) is the least representative model of all models in the sites of Biskra and Ghardaia. It represents the lowest coefficient of 
determination $(0,8314$ for Biskra site and 0,8760 for Ghardaia as noted in Table 3). For Tamanraset site the least model is Modell.

Table 3. Statistical indicators values of models studied.

\begin{tabular}{|c|c|c|c|c|}
\hline Models & $\mathrm{R}^{2}$ & $\begin{array}{c}\mathrm{MBE} \\
\left(\mathrm{Wh} / \mathrm{m}^{2} / \mathrm{D}\right)\end{array}$ & $\begin{array}{c}\text { RSME } \\
\left(\mathrm{Wh} / \mathrm{m}^{2} / \mathrm{D}\right)\end{array}$ & $\begin{array}{l}\text { MPE } \\
(\%)\end{array}$ \\
\hline $\begin{array}{l}\text { Mod1 } \\
\text { Bis } \\
\text { Gha } \\
\text { Tam }\end{array}$ & $\begin{array}{l}0,8669 \\
0,8944 \\
0,7694\end{array}$ & $\begin{array}{l}-0,17 \\
-0,15 \\
-0,07\end{array}$ & $\begin{array}{l}0,832 \\
0,789 \\
0,569\end{array}$ & $\begin{array}{r}1,738 \\
1,691 \\
-0,022\end{array}$ \\
\hline $\begin{array}{l}\text { Mod2 } \\
\text { Bis } \\
\text { Gha } \\
\text { Tam }\end{array}$ & $\begin{array}{l}0,9314 \\
0,9404 \\
0,8883\end{array}$ & $\begin{array}{l}-0,17 \\
-0,15 \\
-0,01\end{array}$ & $\begin{array}{l}0,748 \\
0,728 \\
0,393\end{array}$ & $\begin{array}{l}2,597 \\
2,150 \\
0,472\end{array}$ \\
\hline $\begin{array}{l}\text { Mod3 } \\
\text { Bis } \\
\text { Gha } \\
\text { Tam }\end{array}$ & $\begin{array}{l}0,9265 \\
0,9284 \\
0,8874\end{array}$ & $\begin{array}{l}-0,06 \\
-0,06 \\
-0,01\end{array}$ & $\begin{array}{l}0,581 \\
0,573 \\
0,393\end{array}$ & $\begin{array}{l}1,696 \\
1,401 \\
0,479\end{array}$ \\
\hline $\begin{array}{l}\text { Mod4 } \\
\text { Bis } \\
\text { Gha } \\
\text { Tam }\end{array}$ & $\begin{array}{l}0,9256 \\
0,9276 \\
0,8874\end{array}$ & $\begin{array}{l}-0,06 \\
-0,06 \\
-0,01\end{array}$ & $\begin{array}{l}0,585 \\
0,576 \\
0,393\end{array}$ & $\begin{array}{l}1,712 \\
1.412 \\
0,479\end{array}$ \\
\hline $\begin{array}{l}\text { Mod5 } \\
\text { Bis } \\
\text { Gha } \\
\text { Tam }\end{array}$ & $\begin{array}{l}0,9359 \\
0,9406 \\
0,8884\end{array}$ & $\begin{array}{l}-0,16 \\
-0,15 \\
-0,02 \\
\end{array}$ & $\begin{array}{l}0,719 \\
0,706 \\
0,395 \\
\end{array}$ & $\begin{array}{l}2,479 \\
2,093 \\
0,434\end{array}$ \\
\hline $\begin{array}{l}\text { Mod6 } \\
\text { Bis } \\
\text { Gha } \\
\text { Tam } \\
\end{array}$ & $\begin{array}{l}0,9172 \\
0,9224 \\
0,8860 \\
\end{array}$ & $\begin{array}{c}-0,11 \\
-0,09 \\
0,20 \\
\end{array}$ & $\begin{array}{l}0,660 \\
0,621 \\
0,444 \\
\end{array}$ & $\begin{array}{l}2,165 \\
1,688 \\
4,102 \\
\end{array}$ \\
\hline $\begin{array}{l}\text { Mod7 } \\
\text { Bis } \\
\text { Gha } \\
\text { Tam } \\
\end{array}$ & $\begin{array}{l}0,8314 \\
0,8760 \\
0,7709 \\
\end{array}$ & $\begin{array}{c}0,01 \\
-0,03 \\
0,09 \\
\end{array}$ & $\begin{array}{l}0,857 \\
0,767 \\
0,567 \\
\end{array}$ & $\begin{array}{l}4,836 \\
3,646 \\
2,681 \\
\end{array}$ \\
\hline $\begin{array}{l}\text { New Mod } \\
\text { Bis } \\
\text { Gha } \\
\text { Tam }\end{array}$ & $\begin{array}{l}0,9413 \\
0,9521 \\
0,8914 \\
\end{array}$ & $\begin{array}{l}0,001 \\
0, .001 \\
0,004\end{array}$ & $\begin{array}{l}0,502 \\
0,449 \\
0,384 \\
\end{array}$ & $\begin{array}{l}0,784 \\
0,617 \\
0,559 \\
\end{array}$ \\
\hline
\end{tabular}

All the sites of Biskra, Ghardaia and Tamanrasset follow the same order of the models, Model5 is the best one followed by Model2, then Model3 and Model4 and finally Model6.

It is observed from all these Models that the ratio of global solar radiation to the extraterrestrial radiation $\left(\mathrm{G} / \mathrm{G}_{0}\right)$ depends of the maximum temperature $\left(\mathrm{T}_{\max }\right)$ and the minimum temperature $\left(\mathrm{T}_{\mathrm{min}}\right)$. The variation of daily global solar radiation $(G)$ at Biskra, Ghardaia and Tamanrasset cities according to the daily extraterrestrial radiation $\left(\mathrm{G}_{0}\right)$ follows a linear law. The determination coefficients of these correlations are of $0.9413,0.9512$ and 0.8914 respectively. In addition, the evolution of daily global solar radiation received on horizontal surface at these cities is proportional to the temperature sum $\left(\mathrm{T}_{\max }+\mathrm{T}_{\min }\right)$ for $\operatorname{Biskra}\left(\mathrm{R}^{2}=0.622\right), \operatorname{Ghardaia}\left(\mathrm{R}^{2}=0.625\right)$ and Tamanrasset $\left(\mathrm{R}^{2}=0.609\right)$.

Based on these results, the following models aiming to estimate the daily global solar radiation received on horizontal surface at Biskra, Ghardaia and Tamanrasset sites, can be proposed. They are presented as a function of daily extreme temperatures $\left(\mathrm{T}_{\max }, \mathrm{T}_{\min }\right)$ and daily extraterrestrial radiation. They are given as follows for Biskra, Ghardaia and Tamanrasset sites:

$$
\begin{aligned}
& G=-1,578+0,8.3 G_{0}+0.000701\left(T_{\max }+T_{\min }\right) \\
& G=-1,864+0.8877 G_{0}-0,00431\left(T_{\max }+T_{\min }\right) \\
& G=-0,3566+0,7633 G_{0}-0,01274\left(T_{\max }+T_{\min }\right)
\end{aligned}
$$

For a better representation of our results a comparison between the monthly global solar radiations measured and calculated using this new model and model5 was performed for the three sites (Biskra, Ghardaia and Tamanrasset)( Figure 1). As seen, the calculated values using the new model fit well to the measured ones.

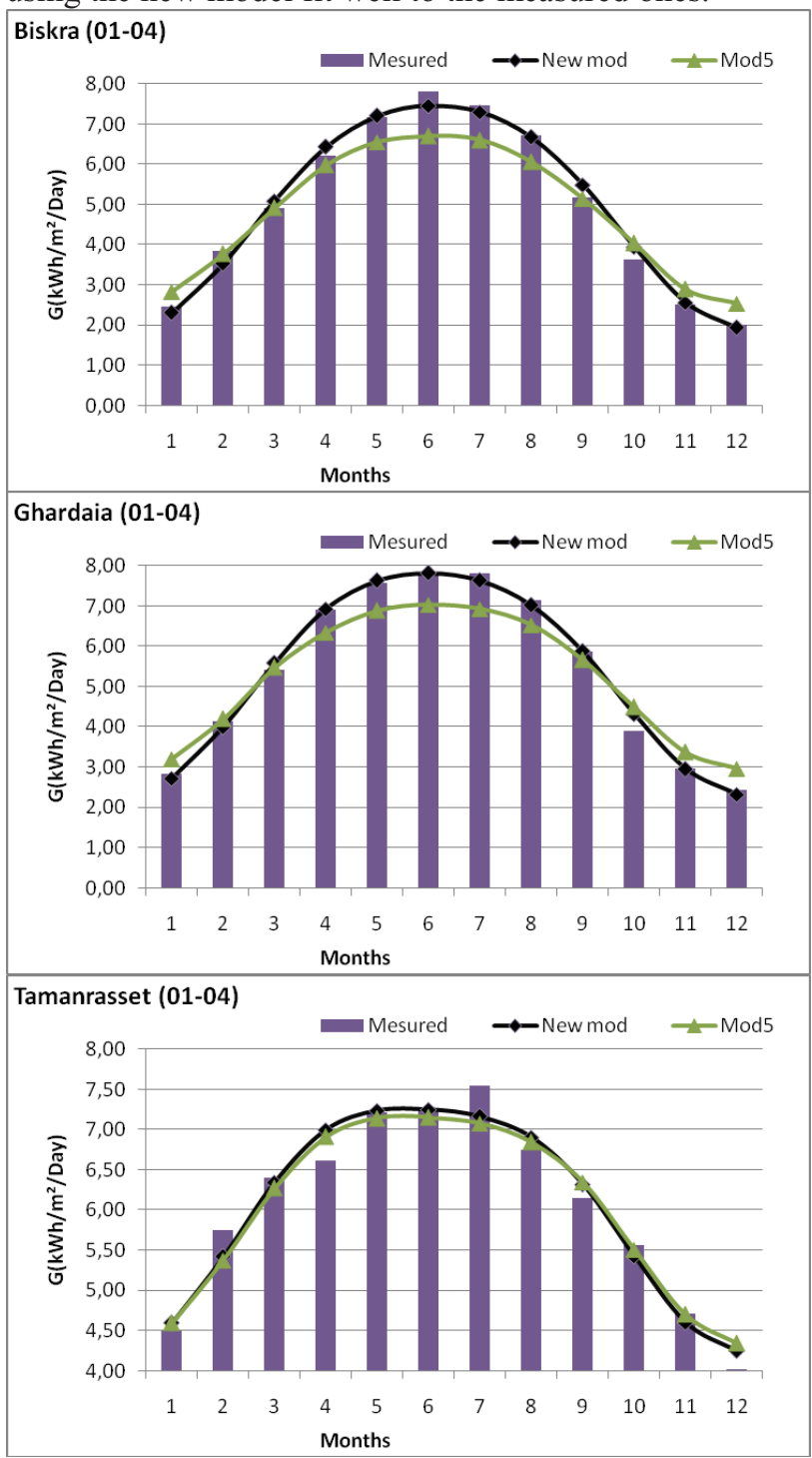

Fig. 1. Comparaison between monthly global solar radiation measured and calculated using the new model and Model5 for all sites..

For Biskra site, the new model for daily global solar radiations has a coefficient of determination $\mathrm{R}^{2}$ of 0,9413 , which is greater than that of the best model Model 5 with a value of 0,9359 as seen in Table 3 . It presents a value of $0,7840(\%)$ for MPE, a value of $0,502\left(\mathrm{kWh} / \mathrm{m}^{2} /\right.$ Day $)$ for RMSE and a value of $0.001\left(\mathrm{kWh} / \mathrm{m}^{2} /\right.$ Day $)$ for MBE, which are less than those found for Model 5 (2,479 (\%) for MPE, 0.719 for RMSE and $-0.16\left(\mathrm{kWh} / \mathrm{m}^{2} / \mathrm{Day}\right)$ for $\mathrm{MBE}$ ). For Ghardaia site, the proposed model has a 
coefficient of determination $\mathrm{R}^{2}$ of 0.9521 , which is greater than that of the best model Model 5 with a value of 0,9406 . It presents a value of $0,617(\%)$ for MPE, a value of $0,449\left(\mathrm{kWh} / \mathrm{m}^{2} /\right.$ Day) for RMSE and a value of $0.001\left(\mathrm{kWh} / \mathrm{m}^{2} /\right.$ Day $)$ for MBE, which are less than those found for Model 5 (2,093(\%) for MPE, 0.706 for RMSE and $-0.15\left(\mathrm{kWh} / \mathrm{m}^{2} /\right.$ Day $)$ for MBE).

For Tamanrasset site, the proposed model has a coefficient of determination $\mathrm{R}^{2}$ of 0,8914 which is greater than that of the best model Model 5 with a value of 0.8884 . It presents a value of $0.559(\%)$ for MPE, a value of $0.384\left(\mathrm{kWh} / \mathrm{m}^{2} /\right.$ Day) for RMSE and a value of -0.004 $\left(\mathrm{kWh} / \mathrm{m}^{2} /\right.$ Day) for MBE, which are less than those found for Model 5 (0.395 for RMSE and $-0.02\left(\mathrm{~W} / \mathrm{m}^{2}\right)$ for MBE).

\section{Conclusion}

Our model describes daily global solar radiations as a linear function of extraterrestrial radiation and the sum of the maximum and minimum temperature. The coefficients of this model depend on the chosen site. It was applicable for three sites of Algeria. It is the best one in the series of the models studied. It allows determining the evolution of daily global solar radiation using only the extreme temperature values (maximum and minimum) in the south of Algeria.

\section{References}

1. M. R. Yaich, A. Bouhanik, S. M. A. Bekkouche, A. Malek, and T. Benouaz, Energ. Convrs. Manage, 82, (2014)

2. F. Besharat, A. A. Dehghan, A. R. Faghih, Renew Sust. Energ. Rev, 21, (2013)

3. A. Das, J-k. Park, J-h. Park, J. Atmos. Sol-Terr. Phy, 134, (2015)

4. M. EL-Metwally, J. Atmos. Sol-Terr. Phy, 67, (2005)

5. L. Supit, RR. V. Kappel, Sol. Energy, 63, (1998)

6. V. Badescu, Theor. Appl. Climato, 72, (2002)
7. PE. Thornton, SW. Running, Agric. For. Meteorol, 93, (1999)

8. G. H. Hargeaves and Z. A. Samani, J. Irrig. Drain. Div, 108(3), (1982)

9. K. L. Bristow, and G. S. Campbell, Agric. For. Meteorol, 31(2), (1984)

10. R. Allen, J. Hydrol. Eng, 2, (1997)

11. R. Chen, K. Eric, J. Yang, S. Li, and W. Zhao, Energ. Convrs. Manage, 45(11-12), (2004)

12. R. Meenal, P. G. Boazina, A. I. Selvakumar, Indian J. Sci Technol, 9(46), (2016)

13. J.D.S Valdineny, R.D.S. Claudio, A.J. José Aust. J. Crop Sci, 10(7), (2016)

14. Z. Samani, J. Irrig. Drain. Div Eng, 126(4), (2000)

15. H. Li, F. Cao, X. Wang and W. Ma, The Sci World J, 3: (2014)

16. M. Donatell, G.S. Campbell, Proceeding sof the fifth European society of agronomy congress, Nitra, Slovak Republic. (1998)

17. J. D. G. Goodin, M. S. Hutchinson, R. L. Vanderlip, M. C. Knapp, Agron. J, 91, (1999)

18. A. Weiss, C. J. Hays, Q.Hu, W. E. Easterling, Agron. J, 93, (2001)

19. M. G. Abraha, M. J. Savage,. Agric. For. Meteorol, 148, (2008)

20. M. F. Li, H. B. Li, P.T. Guo, W. Wu, Energ. Convrs. Manage, 51, (2010)

21. G. N. Okonkwo, A. O. C. Nwokoge, ESJ, 10( 15), (2014)

22. M. G. Abraha, M. J. Savage, Agric. For. Meteorol, 148, (2008)

23. V. H. Quej, J. Almorox, M. Ibrakhimov, L.Saito, Energ. Convrs. Manage, 110, (2016)

24. W. Yao, Z. Li, Y. Wang, F. Yiang, L. Hu, Energy Energ. Convrs. Manage, 84, (2014)

25. E. A Sahah, F. A. Uba, journal STR, 2(8), (2013) 